\title{
The Relation between Different Open \\ Innovation Practices and Firm's \\ Innovation Performance
}

Kaja Rangus

University of Ljubljana, Slovenia

kaja.rangus@ef.uni-lj.si

Case study representations and quantitative research in the field of open innovation indicate significant association of open innovation with a firm's innovation performance. However, open innovation is not dichotomous, it consists of several distinct practices. This study aims to contribute to the existing knowledge on open innovation in organisations by disentangling among different open innovation practices, (i.e. inward IP licensing and external participation, outsourcing $\mathrm{R} \& \mathrm{D}$ and external networking, customer involvement, employee involvement, and venturing) and indicating their relation to a firm's innovation performance. We conceptualize a model in which we propose that all open innovation practices significantly relate to a firm's innovation performance. We tested the model on a sample of 693 companies from three countries, and found the most significant relation between employee involvement and firm's innovation performance. Based on a semi-structured interview with a head of open innovation at renowned multinational company, we provide suggestions on how to implement open innovation. We conclude the paper with the discussion of the results for business practitioners, suggesting effective approaches for incorporation of open innovation in their business practice.

Key Words: open innovation, innovation performance, employee involvement

JEL Classification: 031, 032, 033

https://doi.org/10.26493/1854-6935.15.61-79

\section{Introduction}

The concept of open innovation has received substantial attention in the recent decade, from case study representations to in-depth scientific research among large as well as small and medium sized enterprises (sMEs). The main idea of open innovation is collaboration with external partners, exploration of their knowledge and technology, and exploitation of internal resources (Chesbrough 2003; 2006). The link between open innovation and business performance is most evident from case studies of 
renown multinationals. For example, Procter \& Gamble (P\&G) has, in the last decade, recorded incredible boosts of innovation performance due to the creation of an open business model named Connect \& Develop $(C \& D)$. The $C \& D$ model was established in 2000 with the aim of saving the company from downturn and accelerating business growth (Chesbrough 2007).

The goal of $\mathrm{C} \& \mathrm{D}$ has been to find good ideas, bring them inside to enrich and exploit internal capabilities, explore external resources and consequently create new products, connecting what was not obvious (Huston and Sakkab 2006). As P\&G's Dr. Mike Addison stated: 'Innovation is all about making new connections. Most breakthrough innovation is about combining known knowledge in new ways or bringing an idea from one domain to another' (Dodgson, Gann, and Salter 2006, 337). The success of $C \& D$ has been in addition to the other aspects of innovation - those related to product costs, design, and marketing, evident also in the productivity of P\&G'S R\&D activities, which has improved almost by $60 \%$. The success in innovation has more than doubled, and the R\&D investment has dropped by $30 \%$ (Huston and Sakkab 2006). The competitive advantage of involving external partners in the innovation process is apparent also in the case of Apple, which attracted many third-party applications and services that created novel experiences for Apple users; 'even perfectionist Steve Jobs realised the value of letting others into the Apple innovation process' (Chesbrough 2011, 19).

Nevertheless, open innovation is not unidimensional (Dahlander and Gann 2010; Chesbrough 2003). It consists of several distinct practices, such as collaboration with various partners, customer involvement, venturing, IP in-licensing, and IP out-licensing (Chesbrough 2003; van de Vrande et al. 2009). Despite these multiple practices, the multidimensional phenomenon of open innovation has been rarely explored as a whole. Instead, existing research has focused mostly on one of its practices. With this study, we aim to contribute to the existing knowledge on open innovation in organisations in the following ways.

First, in contrast to existing studies that only focus on partial aspects of open innovation, we take an integrative perspective and provide a comprehensive overview of open innovation activities. Drawing from an indepth literature review of open innovation, we have grounds to evaluate and compare the utility of each activity in attaining innovation-related outcomes in organisations. We provide a systematic description of the multiple practices of open innovation and in this way help managers to 
understand the complexity of this phenomenon and its activities, which have been fragmented and dispersed across several studies. Understanding contributions of individual open innovation practices is important in implementing effective decision making processes in organisations, specifically by CEOS in organisations that compete in dynamic business environments in which the innovation imperative is even more important (Zhou, Kin, and Tse 2005).

To disentangle the relative importance of a particular open innovation practice to an organisation's innovation performance, we performed quantitative analysis on a large sample of companies from three countries. In so doing, we provided evidence as to which open innovation practices should be given the most attention and be stimulated the most. Furthermore, with an aim to get additional insights on the key challenges and important elements for successful open innovation implementation within organisations, we carried out a semi-structured interview with a head of open innovation at a renowned multinational company.

The paper proceeds as follows. We first summarize existing literature on open innovation practices in relation to a firm's innovation performance. On this basis, we propose the conceptual framework and develop hypotheses. We then tested the proposed model on a sample of 693 companies from three countries. What follows is a discussion on the importance of employee involvement in firm's innovation performance and guidelines for successful implementation of open innovation. We conclude with the discussion of implications for theory and practice, limitations of our study and future research opportunities.

\section{Open Innovation and a Firm's Innovation Performance}

Although existing research on open innovation is prevalently limited to qualitative studies, more empirical studies have recently emerged. For example, Laursen and Salter's (2006) findings based on the UK innovation survey suggested a curvilinear relationship between external search breadth and external search depth and innovation performance. In another study on a sample of 141 companies from three countries, Inauen and Schenker-Wicki (2011) showed that openness of the outside-in process positively relates to a firm's innovation performance; in particular, collaboration with customers and universities positively relates to product innovations, while openness towards suppliers, competitors, and universities is linked to process innovations.

However, only a few studies have considered the multidimensionality 
of a firm's open innovation process. In their study, Van de Vrande et al. (2009) cluster analysed 605 companies from Netherlands into three clusters regarding their intensity on several practices of open innovation to find three distinct clusters of companies. The first (and smallest) cluster of companies was high on all open innovation practices; the second cluster of companies was intense on open innovation activities associated with employee and customer involvement and external networking; and the third cluster of companies implemented solely customer involvement practice. These authors did not analyse the relationship between open innovation practices and innovation performance.

Similarly, Schroll and Mild (2011) cluster analysed 18o European companies into groups based on their inbound open innovation cooperation, acquisition, and outbound open innovation. Although the authors observed different practices of open innovation, the study mainly pointed to the dynamics of adoption of inbound and outbound open innovation activities across European companies, without implying how open innovation relates to their innovation performance. Lazzarotti, Manzini, and Pellegrini (2010) examined different models for opening up the innovation process, taking into consideration partner variety (the number and type of partners with whom the company collaborates) and phase variety (the number and type of phases of the innovation process open to external collaborations). They identified four groups of companies: open innovators, who cooperate with a wide set of partners in many phases of the innovation process; specialised collaborators, who open only a small part of the innovation process to a wide variety of partners; integrated collaborators, who cooperate with a limited set of partners along the whole innovation funnel; and closed innovators, who open a very small part of the innovation funnel to a very limited set of partners.

Additionally, these authors analysed the relation between the two open innovation practices and a firm's innovation performance to find that open innovators had superior innovation performance as compared to companies in the other three groups. According to the authors, their findings need to be interpreted with caution and are not representative of open innovation phenomenon as a whole because they are based on a small sample of 99 companies analysing one specific practice of open innovation.

In summary, prior research of open innovation has lacked empirical evidence of how particular open innovation practices relates to a firm's innovation performance. Moreover, existing literature does not provide 
suggestions on how different open innovation activities can be effectively implemented by taking into account the human centeredness of open innovation. Below, we build a theory to support our arguments about relationships between open innovation practices and a firm's innovation performance.

\section{DIFFERENT PRACTICES OF OPEN INNOVATION}

First, to establish particular relationships between open innovation practices and a firm's performance, we summarise existing open innovation literature that suggests that open innovation involves two important facets - inbound and outbound open innovation, and several activities associated with either two.

Open innovation consists of two parts: the first one indicates that firms should open up to leverage the discoveries of others, and the second part stresses the importance of sharing internal knowledge and technology with external partners (Chesbrough 2006). Inbound open innovation can be acquired with open innovation practices, such as external participation, inward IP licensing, external networking, outsourcing $\mathrm{R} \& \mathrm{D}$, and customer involvement; in contrast, outbound open innovation can be realised through outward IP licensing, employee involvement, and venturing activities (van de Vrande et al. 2009).

THE RELATION BETWEEN THE SEPARATE PRACTICE OF OPEN INNOVATION AND A FIRM'S INNOVATION PERFORMANCE

Existing research provides overall support for the argument that there is a relationship between inbound and outbound open innovation activities and innovation performance (Chesbrough and Crowther 2006; Chesbrough 2003). This strong support is evident because inbound open innovation enables firms to reach external sources of knowledge and technology, which facilitate internal innovation processes; on the other hand, outbound open innovation generates additional value in the innovation by reaching external channels to market outside the traditional business of the firm (Chesbrough 2006).

Given the overall support for the relationship between open innovation and innovation performance, we develop arguments for specific relationships among open innovation practices: outsourcing $\mathrm{R} \& \mathrm{D}$ and $\mathrm{ex}-$ ternal networking, customer involvement, inward IP licensing and external participation, employee involvement, and venturing and innovation performance. 


\section{Outsourcing $R \nLeftarrow D$ and External Networking}

Organisations that rely upon a greater number of external search channels have a superior capability to sustain exchanges and collaborations with external partners. This approach facilitates the gain and exploitation of innovative opportunities available to them, which positively relates to the firm's innovation performance (Laursen and Salter 2006). The overall positive effect of external networks on innovation has been also shown by Inauen and Schenker-Wicki (2011). Among resources in the networks, creativity, fresh ideas on product innovation, and know-how to implement such innovations (Schroll and Mild 2011) significantly contribute to market push innovations (Nijhof, Krabbendam, and Looise 2002). In collaborating with universities, companies also gain new technological and scientific capabilities that are accessible through specialised and expertise knowledge of scientists (Bishop, D’Este, and Neely 2011). Prior literature has suggested a positive relationship between a firm's innovation performance and its technological and scientific capabilities (Fabrizio 2006). We propose:

$\mathrm{H} 1$ There is a direct positive relationship between outsourcing $R \leftrightarrow D$ and external networking and innovation performance of a firm.

\section{Customer Involvement}

Customer involvement was in prior research shown to positively relate to a firm's innovation performance (Inauen and Schenker-Wicki 2011). This positive association emerged from customers' expressing their needs, which can be a great source of innovative ideas for new products and services and for continuously improving existing ones (Chesbrough 2003). The involvement of customers in the innovation process can be direct, such as by developing products based on their specifications (van de Vrande et al. 2009), or indirect, such as by equipping customers with toolkits for the development and testing of prototypes so that they can improve prototypes until the products match their requirements (von Hippel and Katz 2002). The innovative engagement of customers is longstanding and evolving, and some of their creations may be attractive to other customers (Prugl and Schreier 2006). The case of $3 \mathrm{M}$ shows that the innovations developed by customers have delivered sales 8 times higher than innovations developed in the traditional manner (Von Hippel 2005).

This evidence leads us to propose: 
$\mathrm{H} 2$ There is a direct positive relationship between customer involvement and innovation performance of a firm.

\section{External Participation and Inward IP Licensing}

Formalised relationships among companies, such as joint ventures, positively relate to patent results (Santamaría, Nieto, and Barge-Gil 2009). In case of complex innovation process, specific interdisciplinary knowledge and capabilities are required, which are hard to gain through marketbased resources and are therefore attained through more heterogeneous alliances, for example non-equity alliances with more than one type of partner (Santamaría, Nieto, and Barge-Gil 2009). In addition, IP inlicensing enables the focal firm to save on time and development costs, and therein gain already verified technologies that enable the development of more sophisticated products (Tao and Magnotta 2006). Based on this evidence we hypothesise:

H3 There is a Direct Positive Relationship between External Participation and Inward IP Licensing and Innovation Performance of a Firm.

\section{Employee Involvement}

Innovation process can be stimulated via employee involvement, exploiting the knowledge and ideas of employees who are not involved in the R\&D activities (van de Vrande et al. 2009). Employees can facilitate new innovations via internal collaboration among divisions that facilitate sharing and borrowing of ideas (O'Connor 2005). Another approach to employee involvement is their stimulation of searching for patentable ideas within and outside the organisation (Chesbrough 2003). Absorptive capacity enables firms to attain, integrate, transform and exploit knowledge with an aim of sustainable competitive advantage (Zahra and George 2002).

It relates to the ability of identification and exploitation of specific technological knowledge, its assimilation and application to commercial ends (Cohen and Levinthal 1989; 1990). Highly competent employees have greater absorptive capacities and superior abilities to transfer perceptions inside the company, and in this way they facilitate innovation activities (Knudsen 2007). We hypothesise:

H4 There is a Direct Positive Relationship between Employee Involvement and Innovation Performance of a Firm. 


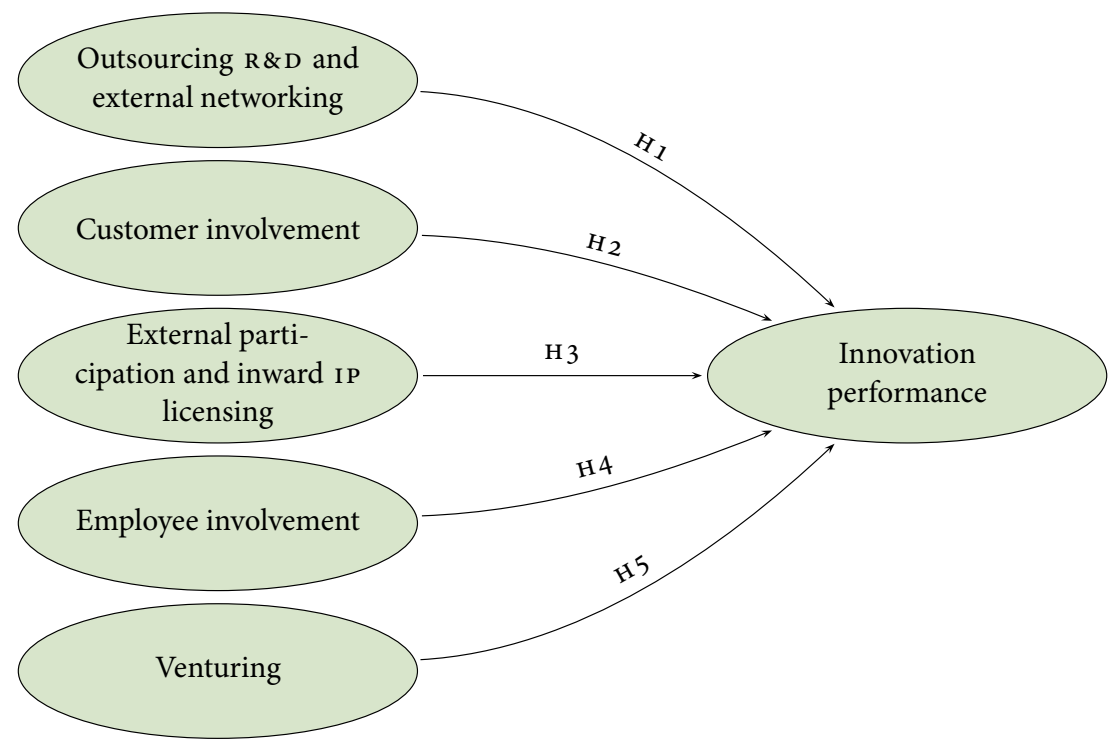

FIgURE 1 The Hypothesised Relations Between Open Innovation Practices and Firm's Innovation Performance

\section{Venturing}

Internal technological capabilities can be commercialised with venturing (van de Vrande et al. 2009) that helps organisations to enter new markets and industries (Block and MacMillan 1995) and reach information about imminent technologies and market prospects (Chesbrough 2003). In these ways, organisations provide potential opportunities for innovation breakthrough. We anticipate:

$\mathrm{H} 5$ There is a Direct Positive Relationship between Venturing and Innovation Performance of a Firm.

The hypothesised relations come together in the model presented in figure 1.

\section{Methodology and Data Analysis}

We chose three distinct national contexts for gathering data for the research: Italy, a cultural, political, and religious centre of Western civilisation; Slovenia, a young, small economy with a socialist past, and Belgium, a sovereign state with a rich political history and a complex system of governance. Despite being a part of European Union, some specific contextual differences exist in their business environment. For example, 
according to Hofstede's country comparison, Slovenia scored much lower in the individualism and masculinity dimensions than Italy and Belgium. On the other side, Slovenia scored higher than the two countries in the power distance dimension. Moreover, the Innovation Union Scoreboard 2016 classified Belgium among the best countries within the Strong Innovators group. Slovenia ranked at the bottom of this group (with the innovation performance below the EU average), but outperformed Italy, which classified among Moderate Innovators.

However, according to the Eurostat statistics, the company structure of these countries is very similar to the European Union average, having more than $99 \%$ of sMEs among active enterprises in the country, with the highest number of companies classified to distributive trades, following by professional, scientific and technical activities, construction and manufacturing. Therefore, the aim of incorporating different national contexts is to provide greater consistency of the results (and not making them country-specific).

The data were obtained via online surveys administered to CEOS of Italian, Slovenian, and Belgian companies. 1250 Italian companies were randomly selected from the Amadeus database in October 2012, 2000 Slovenian manufacturing and service firms from the PIRS database in May 2013, and 1500 Belgian companies from the Bel-First database in June 2013. The response rates were as follows: 99 valid responses in Italy (7.9\% response rate), 421 valid responses in Slovenia (21.1\% response rate), and 173 valid responses in Belgium (11.5\% response rate), composing the total sample of 693 companies from three countries. The sample included different firm's sizes and a wide range of industries (the majority belonging to manufacturing, information and communication, and service activities). The sample composition is presented in table 1.

\section{INDEPENDENT VARIABLES}

We used proclivity for open innovation scale developed and validated by Rangus, Drnovšek, and Di Minin (2016) to measure the following open innovation practices: inward IP licensing and external participation, outsourcing R\&D and external networking, customer involvement, employee involvement, and venturing. All responses were evaluated on a 7-point Likert scale (e.g. $1=$ strongly disagree; $7=$ strongly agree). To validate the dimensionality of the measure, we conducted CFA using Lisrel 8.80 and checked for their internal consistency using Cronbach's alphas (calculated using Iвм SPSs Statistics 20). 
TABLE 1 Sample Composition (\%)

\begin{tabular}{llrrrr}
\hline Category & & $(1)$ & $(2)$ & $(3)$ & $(4)$ \\
\hline Size & Micro (o-9 employees) & 33.3 & 11.5 & 23.3 & 26.4 \\
& Small (10-49 employees) & 46.6 & 38.2 & 27.3 & 41.7 \\
& Medium (50-249 employees) & 11.9 & 27.2 & 16.2 & 16.3 \\
& Large (250 employees or more) & 8.3 & 23.1 & 33.3 & 15.6 \\
\hline Industry & Agriculture and mining & 2.4 & 4.00 & 3.0 & 2.9 \\
& Manufacturing sector & 34.0 & 34.1 & 35.4 & 34.2 \\
& Service sector & 41.6 & 42.2 & 41.4 & 41.7 \\
& Construction & 9.5 & 10.4 & 9.1 & 9.7 \\
& Public sector & 12.6 & 9.2 & 11.1 & 11.5 \\
\hline
\end{tabular}

NOTES Column headings are as follow: (1) Slovenian sample $(n=421)$, (2) Belgian sample $(n=173)$, (3) Italian sample $(n=99)$, (4) sample composition $(n=693)$.

Due to low standardised loadings, we excluded four items from further analysis. The excluded items were: (a) 'To ensure successful development of new products/services, we usually buy the IP of other companies,' which belongs to factor Inward IP licensing and external participation; (b and c) 'In order to acquire new know-how/technology, we cooperate with consultancy companies' and 'In order to acquire new knowhow/technology, we cooperate with competitors', both of which belong to factor Outsourcing R\&D and external networking; and (d) 'Members of our staff include idea seekers who look for potentially useful knowhow/technologies outside the company', which belongs to factor Employee involvement.

Cronbach's alphas of the five practices ranged between 0.77 and 0.86 and were consistent with the previous research of Rangus, Drnovšek, and Di Minin (2016) that reported the range of Cronbach's alphas from 0.76 to 0.88 .

\section{DEPENDENT VARIABLE}

We measured innovation performance with Jiménez-Jiménez and SanzValle (2011) measure. With this measure, respondents evaluated various aspects of a firm's innovation performance against the major competitors in the industry in the last 3 years on a 7-point Likert scale ranging from much worse than competitors to much better than competitors. The construct exhibited high internal consistency with the Cronbach's alpha of 0.91 . 
TABLE 2 Results of the Regression Analysis

\begin{tabular}{lrrrrr}
\hline Variable & $(1)$ & $(2)$ & $(3)$ & $(4)$ & $(5)$ \\
\hline Employee involvement & 0.365 & 0.036 & 0.376 & 100.286 & 0.000 \\
Venturing & 0.114 & 0.034 & 0.125 & 30.325 & 0.001 \\
Outs. R\&D and external networking & 0.081 & 0.032 & 0.090 & 20.538 & 0.011 \\
Firm size & 0.078 & 0.034 & 0.079 & 20.272 & 0.023 \\
Customer involvement & 0.075 & 0.034 & 0.079 & 20.233 & 0.026 \\
\hline
\end{tabular}

Notes Column headings are as follows: (1) $B$, (2) standard error (unstandardized coefficients), (3) $\beta$ (standardized coefficient), (4) $t$, (5) significance.

We reduced the data and built the final practices constituting the components for regression analysis using summated scales. We also checked for the potential of high correlation between the practices using correlation analysis, where no correlation exceeded the value of 0.5 .

\section{CONTROL VARIABLES}

We included three control variables in the model. We controlled for the differences in the national context differentiating among the three countries (Slovenia, Belgium, and Italy). At the firm level, we controlled for firm size (measured with the number of employees) and firm industry (differentiating among agriculture and mining, manufacturing sector, service sector, construction, and public sector).

\section{Results}

The regression analysis was performed using г в м s Pss Statistics 20. We evaluated the relationship between a specific practice of open innovation and a firm's innovation performance using linear regression analysis. We used stepwise estimation model to include the variables into the model, as this method starts by selecting the best predictor of the dependent variable, and continues by including other variables according to the incremental explanatory power they can add to the model and dropping the variables with insignificant level of predictive power (Hair et al. 2010). Results of the regression analysis are presented in table 2 and excluded variables in table 3 .

The regression analysis supported the hypotheses with the following results: outsourcing $\mathrm{R} \& \mathrm{D}$ and external networking $(\beta=+0.09, p \leq$ $0.05)$, customer involvement $(\beta=+0.08, p \leq 0.05)$, employee involvement $(\beta=+0.38, p \leq 0.001)$, and venturing $(\beta=+0.13, p \leq 0.001)$, 
TABLE 3 Excluded Variables

\begin{tabular}{lrrr}
\hline Variable & $(1)$ & $(2)$ & $(3)$ \\
\hline External participation and inward IP licensing & 0.054 & 10.309 & 0.191 \\
Firm industry & 0.033 & 0.974 & 0.331 \\
Country & 0.049 & 10.371 & 0.171 \\
\hline
\end{tabular}

Notes Column headings are as follows: (1) $\beta,(2) t$, (3) significance.

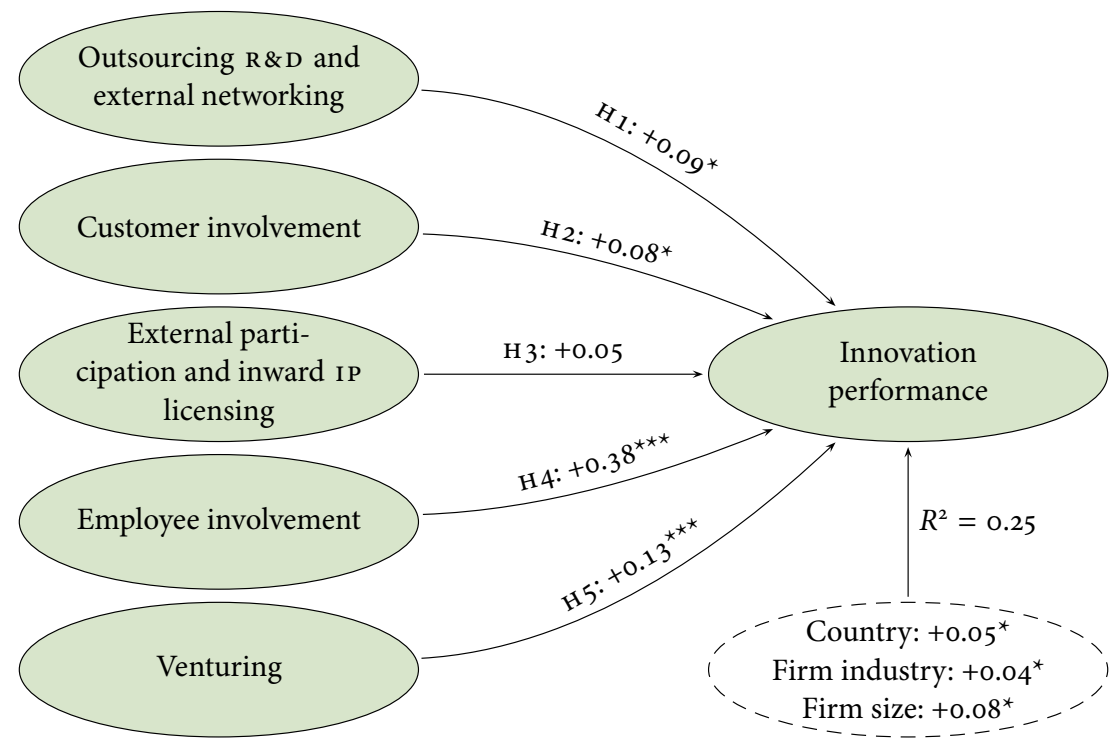

FIGURE 2 Results of the Hypothesised Relations ( ${ }^{*}$ significant at $p \leq 0.05$, ${ }^{* * *}$ significant at $p=\leq 0.001$ )

with the exception of Hypothesis 3 that proposed a positive relationship between inward IP licensing and external participation and a firm's innovation performance (the relationship was positive but not significant). The results of the regression analysis (presented in figure 2) exhibited the strongest relationship between employee involvement and a firm's innovation performance.

Among the control variables only firm size exhibited significant (positive) relation with the innovation performance of a firm. In particular, the results suggest, that the larger the firm the superior the innovation performance. This may be due to the fact that larger firms possess the resources for R\&D investments and consequently develop more innovations (in terms of new product/service development) (Damanpour 1992). 


\section{Findings}

An important aspect raised in this study is the importance of the employee involvement practice. This practice turned to have the most significant relationship with a firm's innovation performance among the selected open innovation practices. Previous studies showed that high performance work practices, which include employee recruitment, incentive compensation, employee involvement, and training, are associated with lower employee turnover, greater productivity, and corporate financial performance (Huselid 1995). Our study adds to the existing evidence on the importance of employee involvement by displaying their significant relation to innovation performance. Therefore, managers have to dedicate special attention to the development and personal growth of employees.

As we emphasised earlier in the paper, the absorptive capacity of employees to identify, integrate, and combine externally acquired knowledge and technology facilitates innovation outcomes. Moreover, the greater the employees' competences, the greater their absorptive capacities (Knudsen 2007). Competences of employees may be raised by forming rotational assignments through which different interactions internally and externally enhance the sharing and borrowing of ideas (O'Connor 2005). Another important aspect is raising awareness, especially among researchers, about the business side of innovation and rewarding them for identifying patentable ideas within as well as outside the firm's boundaries (Chesbrough 2003).

Furthermore, with an aim to get additional insights on how to effectively implement open innovation process within organisations, we executed a semi-structured interview with Lucia Chierchia, head of open innovation at Electrolux. In her view, 'the key challenge of open innovation is the creation of synergies between people inside and outside the company' Therefore, the implementation of open innovation should first start with the identification of an open innovation network - that is, the network of partners outside the trusted network of the company (i.e., the network of long-standing partnerships with associates they know and trust). Collaboration with the trusted network is not open innovation, but a normal way of business.' So 'the challenge is to reach and interact with people/organisations that we don't know; and because we don't know them we cannot trust them. This is open innovation.'

The network should consist of different partners, including suppli- 
ers, customers, companies from different industries, start-ups, universities, research institutes, laboratories, individual researchers and inventors, venture capitals, etc. These partnerships can be established informally by way of a 'facial or virtual word of mouth approach', connecting with new partners through acquaintances or more formally by way of platforms/online communities (such as Nine Sigma, Innocentive, etc.) that can help at identification of the right partner for new product/service development. 'The challenge is to put the ideas on innovation every day; to transfer ideas into running projects of a company [...] but in parallel we need to constantly enlarge and reinforce the open innovation network'.

However, the grounds for the successful implementation of open innovation are establishment of the open mindsets of internal and external participants. Hence, the human centeredness of open innovation is crucial, and companies need to invest into activities that nurture open mindsets. 'Open innovation is a model of interaction among people - is about people. So it is crucial to consider also the psychological part.' The way they grow open innovation mindsets in Electrolux is through workshops and trainings, motivating employees to overcome the 'Not invented here' syndrome. In addition, they externally promote open innovation mindsets through free webinars for external partners and are also often invited by other organisations to share their knowledge and experiences on open innovation and explain their ways of implementation.

\section{Discussion}

The aim of this research was to contribute to a deeper understanding of how different practices of open innovation relate to a firm's innovation performance and disentangle their relative importance. Using a multidimensional measure related to open innovation enabled us to determine the importance of individual dimensions with regard to a firm's innovation performance; these relationships may be unseen when using a unidimensional scale. Based on a sample of companies from three different countries, we performed regression analysis, underscoring the relation of the individual practice of open innovation with a firm's innovation performance. Our empirical findings suggest that all open innovation practices are positively associated with a firm's innovation performance, with the strongest link of employee involvement. Since the importance of this practice was emphasised through interviews as well, we have discussed it in more detail in a separate subsection. 
In general, the findings suggest that stimulating any open innovation practice may strengthen a firm's innovation performance. The exception to this finding was the practice of the inward IP licensing and external participation, which did not turn out to be significant. This result may denote that solely buying or licensing external technology does not create benefits; firms must have the capabilities to incorporate it and turn this technology into innovation opportunities. This finding supports the notion already emphasized by scholars highlighting the importance of internal $\mathrm{R} \& \mathrm{D}$ for open innovation.

While open innovation promotes collaboration among different partners and exploration of outside knowledge and technology, it does not advise to rely solely on external sources. As stated by Chesbrough and Crowther $(2006,235)$ : 'the concept of open innovation ought not to be interpreted to imply the outsourcing of the entire $\mathrm{R} \& \mathrm{D}$ function. Leveraging external research may function more as a complement than as a substitute in the performance of internal R\&D activities.' A central implication of this study is thus the finding that while searching and collaborating with external environment, organizations should not forget about the internal organizational mechanisms that play a vital part in successful open innovation implementation. Besides the stimulation of the internal development of technology and the search for external resources and collaboration, managers have to pay greater attention to the personal development of employees, nurturing their open mindsets through different trainings, workshops, open communication and collaboration.

Besides determining the relationship of individual dimension with a firm's innovation performance, the multidimensional measure also enables firms to define the interactions of separate dimensions with various internal and external factors that may present fruitful avenues for future research (incorporating distinct boundary conditions in the model). Control variables included in the model denoted significant relation with firm size, supporting the notion that larger companies tend to have superior innovation performance, i.e. are able to innovate faster as they have greater financial resources and capabilities. On the other side, the association with industry type and country was not significant. In terms of open innovation, results are in line with the existing literature which emphasize the significant relation of open innovation with firm size rather that industry (van de Vrande et al. 2009). Van de Vrande and colleagues indicated that manufacturers tend to use $\mathrm{R} \& \mathrm{D}$ outsourcing and outward IP licensing more often and venturing activities are employed more by 
service firms which is an important observation. Open innovation activities which may consequently lead to better innovation performance are thus important for all companies regardless of firm industry. The nonsignificant difference among countries may be related to the fact that the motives for business (e.g. profit motives) and overall aims of innovation performance (e.g. competitive advantage, growth, etc.) may be similar regardless of national context (Spithoven 2013). However, there are several differences in innovation performance of the analysed countries evident, for example from the European Innovation Scoreboard, therefore future research should also devote special attention to the factors which may reveal these hidden differences among industry and national specificities.

Besides the mentioned shortcomings, there are also other limitations of the study, which may present opportunities for future research. One of the main drawbacks relates to the use of cross-sectional data, observing subjects only at one point of time. Incorporating longitudinal analysis may reveal how the use of open innovation practices evolve and change over time. Another limitation relates to the small marginal samples of the companies from Italy (and Belgium). To support the findings of our study, additional research from these national contexts is needed. Another limitation is related to the common method bias, collecting data from a single respondent of a company. We tried to minimize this bias by paying special attention in the research design development and implementation phase. For example, we performed pre-test phase for validating the understanding and objectiveness of the survey instrument, and when sending survey invitations, we searched for the direct addresses of the CEOS. Furthermore, future research should include relative importance analysis that withdraws the problem of correlations among the predictor variables and may therefore contribute to the better understanding of the roles played by each predictor in a regression equation.

Since our research highlighted the importance of the human part of open innovation, future research may devote special attention to these aspects. Future studies may examine the leadership competences and tactics that enable successful open innovation, or competences and skills of employees needed for execution of different open innovation practices. Moreover, research connecting different levels of analysis (e.g. individual, team and leadership levels) are needed to provide evidences on how to successfully lead and manage internal organization for open innovation. 


\section{References}

Bishop, K., P. D’Este, and A. Neely. 2011. 'Gaining from Interactions with Universities: Multiple Methods for Nurturing Absorptive Capacity'. Research Policy 40 (1): 30-40.

Block, Z., and I. MacMillan. 1995. Corporate Venturing: Creating New Businesses within the Firm. Boston, MA: Harvard Business Press.

Chesbrough, H. W. 2003. Open Innovation: The New Imperative for Creating and Profiting from Technology. Boston, m A: Harvard Business Press.

- 2006. 'Open Innovation: A New Paradigm for Understanding Industrial Innovation.' In Open Innovation: Researching a New Paradigm, edited by H. W. Chesbrough, W. Vanhaverbeke, and J. West, 1-12. Oxford: Oxford University Press.

- 2007. 'Why Companies Should Have Open Business Models.' MIT Sloan Management Review 48 (2): 22-8.

- 2011. 'The Case for Open Services Innovation: The Commodity Trap.' California Management Review 53 (3): 5-20.

Chesbrough, H. W., and A. K. Crowther. 2006. 'Beyond High Tech: Early Adopters of Open Innovation in Other Industries.' R\&D Management 36 (3): 229-36.

Cohen, W. M., and D. A. Levinthal. 1990. 'Absorptive Capacity: A New Perspective on Learning and Innovation.' Administrative Science Quarterly 35 (1): $128-52$.

- 1989. 'Innovation and Learning: The Two Faces of R\&D.' The Economic Journal 99 (397): 569-96.

Dahlander, L., and D. M. Gann. 2010. 'How Open is Innovation?' Research Policy 39 (6): 699-709.

Damanpour, F. 1992. 'Organizational Size and Innovation.' Organization Studies 13 (3): 375-402.

Dodgson, M., D. Gann, and A. Salter. 2006. 'The Role of Technology in the Shift towards Open Innovation: The Case of Procter \& Gamble.' R $\mho D$ Management 36 (1): 333-46.

Fabrizio, K. R. 2006. 'The Use of University Research in Firm Innovation.' In Open Innovation: Researching a New Paradigm, edited by $\mathrm{H}$. W. Chesbrough, W. Vanhaverbeke, and J. West, 134-6o. Oxford: Oxford University Press.

Hair, J. F., W. C. Black, B. J. Babin, R. E. Anderson, and R. L. Tatham. 2010. Multivariate Data Analysis: A Global Perspective. 7th ed. Upper Saddle River, NJ: Pearson Education.

Huselid, M. A. 1995. 'The Impact of Human Resource Management Practices on Turnover, Productivity, and Corporate Financial Performance.' Academy of Management Journal 38 (3): 635-72. 
Huston, L., and N. Sakkab. 2006. 'Connect and Develop: Inside Procter \& Gamble's New Model for Innovation.' Harvard Business Review 84 (3): 58-66.

Inauen, M., and A. Schenker-Wicki. 2011. 'The Impact of Outside-in Open Innovation on innovation Performance.' European Journal of Innovation Management 14 (4): 496-520.

Jiménez-Jiménez, D., and R. Sanz-Valle. 2011. 'Innovation, Organizational Learning, and Performance.' Journal of Business Research 64 (4): 40817.

Knudsen, L. G. 2007. 'Opening the Black Box of “Open Innovation:” Organizational practice, Employee Competences, and Knowledge Processes.' Paper presented at the DRUID-DIME Academy Winter PhD Conference on Geography, Innovation and Industrial Dynamics, Aalborg, 25-27 January.

Laursen, K., and A. Salter. 2006. 'Open for Innovation: The Role of Openness in Explaining Innovation Performance among UK Manufacturing Firms.' Strategic Management Journal 27 (2): 131-50.

Lazzarotti, V., R. Manzini, and L. Pellegrini. 2010. 'Open Innovation Models Adopted in Practice: An Extensive Study in Italy'. Measuring Business Excellence 14 (4): 11-23.

Nijhof, A., K. Krabbendam, and J. C. Looise. 2002. 'Innovation through Exemptions: Building upon the Existing Creativity of Employees.' Technovation 22 (11): 675-83.

O'Connor, G. C. 2005. 'Open, Radical Innovation: Toward an Integrated Model in Large Established Firms.' In Open Innovation: Researching a New Paradigm, edited by H. W. Chesbrough, W. Vanhaverbeke and J. West, 62-81. Oxford: Oxford University Press.

Prugl, R., and M. Schreier. 2006. 'Learning from Leading-Edge Customers at The Sims: Opening up the Innovation Process Using Toolkits.' $R \& D$ Management 36 (3): 237-50.

Rangus, K., M. Drnovšek, and A. Di Minin. 2016. 'Proclivity for Open Innovation: Construct Development and Empirical Validation.' Innovation: Management, Policy \& Practice 18 (2): 191-211.

Santamaría, L., M. J. Nieto, and A. Barge-Gil. 2009. 'Beyond Formal R \& D: Taking Advantage of Other Sources of Innovation in Low-andMedium-Technology Industries.' Research Policy 38 (3): 507-17.

Schroll, A., and A. Mild. 2011. 'Open Innovation Modes and the Role of Internal R \& D: An Empirical Study on Open Innovation Adoption in Europe.' European Journal of Innovation Management 14 (4): 475-95.

Spithoven, André. 2013. 'Open Innovation Practices and Innovative Performances: An International Comparative Perspective.' International Journal of Technology Management 62 (1): 1-34. 
Tao, J., and V. Magnotta. 2006. 'How Air Products and Chemicals Identifies and Accelerates.' Research-Technology Management 49 (5): 12-8.

van de Vrande, V., J. P. J. de Jong, W. Vanhaverbeke, and M. de Rochemont. 2009. 'Open Innovation in smes: Trends, Motives and Management Challenges.' Technovation 29 (6-7): 423-37.

von Hippel, E. 2005. The Democratization of Innovation. Cambridge, M A: The mit Press.

von Hippel, E., and R. Katz. 2002. 'Shifting Innovation to Users via Toolkits.' Management Science 48 (7): 821-33.

Zahra, S. A., and G. George. 2002. 'Absorptive Capacity: A Review, Reconceptualization, and Extension.' Academy of Management Review 27 (2): 185-203.

Zhou, K. Z., C. Kin, and D. K. Tse. 2005. 'The Effects of Strategic Orientations on Technology-and-Market-Based Breakthrough Innovations.' Journal of Marketing 69 (2): 42-6o.

This paper is published under the terms of the Attribution-

NonCommercial-NoDerivatives 4.o International (CC B Y-NC-ND 4.o)

License (http://creativecommons.org/licenses/by-nc-nd/4.o/). 